\title{
Influence of Digital Technologies and Its Technological Dynamics on Company Management
}

\author{
Ivana MARTINČEVIĆ*, Goran KOZINA
}

\begin{abstract}
Doing business in the market today is unthinkable without new and modern technology, which is one of the key resources by which companies achieve a sustainable competitive advantage. Digitalization and digital transformation of business includes a number of information and communication technologies (ICT) that are built into business processes and which make it easier for management to do business but also ensure market recognition. Globalization of business affects the expansion and easier access to markets, whereby the management of the company must find new ways and methods of doing business, where the digital transformation of business and new digital and information-communication technologies have an effect on growth and competitive advantage. The ability of an organization to transform its business towards digitalization and application of new digital technologies largely depends on the management of the company and a clear digital strategy as an integral part of the corporate business strategy. In order to investigate the impact of constant and rapid development of digital technologies on the management of the company from the aspect of its acceptance and integration within the company's strategy, a survey was conducted in the territory of the Republic of Croatia and Croatian export companies (micro, small, medium and large) were included in the survey.
\end{abstract}

Keywords: digitalization; digital strategy; digital transformation; digital technology; export companies; information and communication technologies (ICT); management

\section{INTRODUCTION}

The digital transformation of business affects the business of all companies and all industries involved in the global market, which greatly facilitates business and there are ways to do business much more efficiently, better and faster. Digitalization and digital transformation of business facilitate access to new knowledge and capital, facilitate and accelerate the transfer of new knowledge and technologies, but also create and influence business specialization and increase profitability.

Modern businesses need to know and be able to adapt business needs to the challenges of the modern market, i.e. they should have the ability to adapt and transform business to the digital needs of the market. Digital business transformation means recognizing, implementing and use of new technology to develop new business models, systems and platforms that will result in higher levels of efficiency and productivity, but also to create and ensure a sustainable competitive advantage in the market.

There are a large number of tools and techniques of modern digital technologies in the market that can affect the improvement of business performance, make the company recognizable, ensure long-term relationships with market stakeholders. Among the many tools of modern digital technologies are certainly social media, a tool whose growth in implementation and use is visible to both individuals and the business world, thus ensuring greater visibility, greater availability, interactivity with the market and stakeholders, which ultimately leads to the creation of loyal consumers and a sustainable competitive advantage.

Recognition, adoption, implementation and ultimately the use of new technology is a decision of the company's management. In accordance with the business policy of the company, the beliefs and attitudes of the management largely depend on the acceptance and use of new digital technologies. Precisely because of market trends and dynamics, management must be flexible and prone to change and acceptance of novelties and innovations, including new digital technologies, ie strategically oriented towards new digital technologies [1].

The aim of this paper is to investigate and determine whether the management of export companies of the Republic of Croatia (micro, small, medium and large) under the influence of technological changes caused by new digital technologies that are developing rapidly and whose application is constantly growing in the market has developed a vision and strategy of application and use of new digital technologies in business. The research was conducted in 2019 through a randomly selected sample of 194 export companies of the Republic of Croatia.

\section{DIGITAL TECHOLOGIES AND DIGITAL TRANSFORMATION OF BUSINESS}

Companies implement and use a large number of digital technologies in their business, incorporating new technology into business processes, various activities and procedures. Digital business transformation implies the implementation and integration of new digital technology in all business areas of the organization and all its business processes, which greatly affects the change in the way of doing business and conducting business operations. Closely related to the digital transformation of business is the concept of digitalization, that is defined as "the use of digital technologies and data (digitized and originally digital) to generate revenue, improve business and transform business processes and create an environment for digital business in which digital information is crucial" [2].

Digital transformation is also defined as "the change that digital technologies can bring to the business model, products, processes, and organizational structure of a company" [3]. Some authors say that digital transformation is "the application of digital technologies that fundamentally affects all aspects of business and society" [4]. Most authors who explain and interpret the process of digital transformation of business explain and state that digital transformation of business implies the use of new digital technology (social, mobile, analytical, cloud and 
Internet of things) as a key factor by which companies improve their business performance, create and increase the added value of company, ie transform and change their business models and way of doing business from traditional to digital business [5-7].

Globalization and internationalization, and with them the closely related digitalization of business, facilitate access and expansion to numerous world markets, which affects the faster growth and development of companies, especially those oriented to export. It is precisely the internationalization and globalization of business conditioned in some way by digitalization that facilitates and accelerates access to new knowledge, encourages the exchange of knowledge, but also facilitates and accelerates access to new, modern and digital technology.

The digital transformation of business differs from company to company, the recognition and implementation of new digital technology in business processes largely depend on the existing infrastructure but also the acceptance and support by company management. Transformation of business and acceptance of new digital tools, techniques and technologies in business provides the company with a certain level of flexibility, greater visibility, creating long-term partnerships with market stakeholders.

\section{THE ROLE OF TOP MANAGEMENT IN THE DEVELOPMENT OF COMPANY DIGITAL STRATEGY}

The digital transformation of business and the adoption and implementation of new technology within the business processes of the company largely depend on the acceptance of the same by the top management of the company. It is the digital transformation of business that is part of the long-term corporate strategy of the company and its integral part if the company wants to improve its business in accordance with the digital needs of the market and the needs of modern business. Recognizing the importance of new digital technologies and their implementation within the business brings with it a number of challenges that involve appropriate adaptation and change of existing business models.

The implementation and use of new information communication and digital technologies facilitates the transfer of knowledge, capital and innovation. The task of top management is to prepare the organization for the changes that come with the digital transformation of business, its implications, advantages and possible disadvantages. In order for the management of the company to be able to develop and create strategic directions and, accordingly, further development of the company, it must know its internal and external environment. The market distinguishes and classifies those companies that are successful from those that are less successful, all from the aspect of technological progress and development of the organization, which is today a determinant of the market and today's global business.

An important factor that dictates the pace and development of the market today, but also the ability of companies to respond to the challenges that markets pose to organizations is the degree of technology development and the associated digital transformation of business. Technological changes and new digital and information - communication technologies encourage competitiveness between organizations, which can affect the improvement of business performance but also the creation of added value. In line with the intensive and rapid growth and development of new technologies, company management should be prone to change and strategically oriented to the implementation and the use of new digital technologies.

Management is the one that, in accordance with its beliefs, desires and possibilities, is responsible for the adoption and acceptance of new technology within the business and its integration into the business strategy of the company [1].

Through the creation of corporate strategy and defining the strategic direction and direction of company development, company management should include and incorporate the so-called "IT strategy" (technology strategy, strategy of new digital technologies). The integration of "IT strategy" within the corporate strategy of the organization becomes a determinant of how and in what way the company uses the new digital technology.

Technology strategy or "IT strategy" is part or should be part of the company's corporate strategy if the company wants to compete in the global market, with emphasis on top management of the company and recognition, importance and use of new digital technologies and their integration as part of corporate strategy.

The implementation and use of digital technologies and the digital transformation of business today are becoming a strategic tool of the organization in terms of achieving competitiveness and sustainable development and market positioning. Through the technology strategy, the company can have an impact on the industry in which it participates and performs economic activity and thus affects its competitive advantage, and therefore the technology strategy should be an integral part of the company's corporate strategy [8].

The importance of technology in order to achieve market competitiveness should include: (1) which technologies to develop, (2) whether to seek technological leadership in these technologies, (3) the role of technology licensing [8].

A small number of studies deals with the importance of including and integrating IT strategy as an integral part of corporate strategy. A significant research was conducted in the Republic of Croatia and proved that a small number of companies in the Republic of Croatia poorly use modern information technology and a small number have a developed IT strategy, thus competing poorly globally [9].

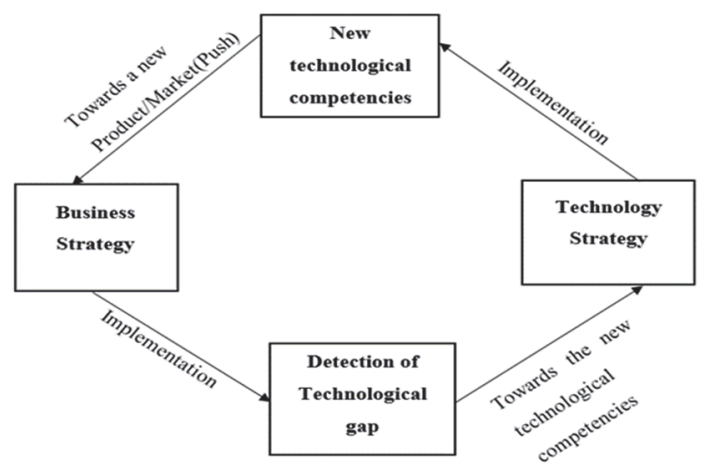

Figure 1 Two directions in bridging the technology strategy and the business strategy [10] 
A model that explains and describes the relationship between the technological and corporate strategy of a company that is in the function of achieving the set goals of the company is presented in Fig. 1.

The digital transformation of business and the related strategy of digital transformation has a focus on the transformation of products, processes, but also organizational aspects of business and new business models based on new technologies [11].

IT strategy as already mentioned should be an integral part of corporate strategy, but digital strategy is intertwined among other strategies, so the inclusion of digital strategy (IT strategy) as part of corporate strategy is an effort and support at the organization level (Fig. 2).

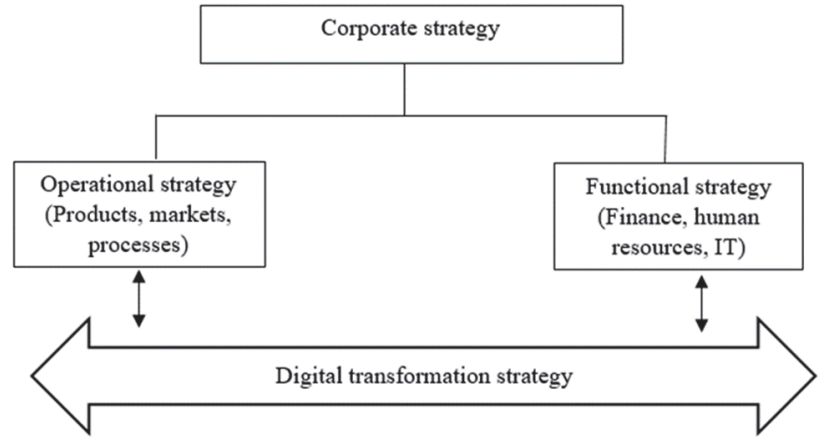

Figure 2 Relation between digital transformation strategy and other corporate strategies [11]

The digital transformation of business and the strategy of digital transformation whose acceptance depends on top management has four important determinants: the use of technology, changes in value creation, structural changes and financial [11]. These four transformation dimensions and their dependencies can be integrated into a common framework of digital transformation are presented in Fig. 3. Taking into account the above four dimensions as part of the framework that supports the development of a digital strategy can be seen as help and support factors in assessing the current capabilities of the company in developing a digital transformation strategy.

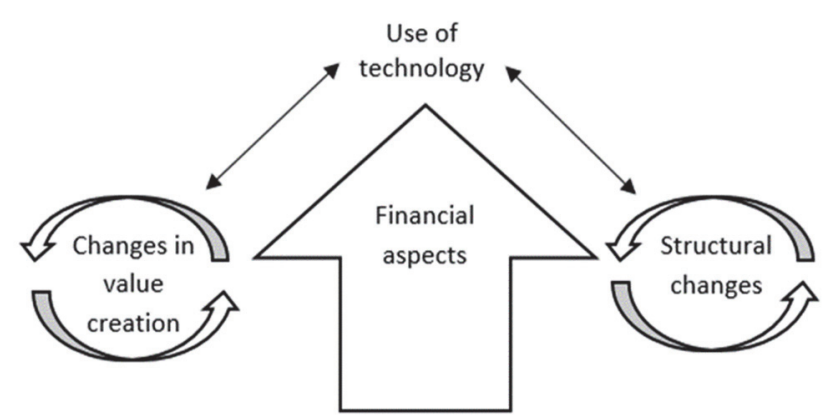

Figure 3 Digital transformation framework: balancing four transformational dimensions [11]

Digital transformation and development of digital business transformation strategy from the aspect of acceptance and implementation of new technology requires support of top management since the inclusion or implementation and use of new technologies requires active involvement of various stakeholders affected by the transformation. Digital transformation today drives various disciplines through numerous researches and influences practice [12].

\section{RESEARCH RESULTS}

As no research has been conducted on the territory of the Republic of Croatia that correlates new technologies and their technological dynamics and their impact on company management, the reason for conducting this research is justified. The research was conducted in the Republic of Croatia, through a randomly selected sample of 194 exporting companies (micro, small, medium and large).The research aims to test the following hypothesis: H1: "New technologies and their technological dynamics have an impact on the top management of Croatian export companies in terms of the representation of new technologies (social media) in business strategy".

The survey was conducted in 2019 electronically, by sending questionnaires to 500 randomly selected addresses, and 194 questionnaires were collected. Respondents were asked to rate the importance of each parameter related to the new technology and their technological dynamics and to evaluate the parameter related to top management using the Likert scale from 1 to 5 (1 - strongly disagree, 5 - strongly agree). Tab. 1 (authors work) and Tab. 2 show the constructs used to test the hypothesis.

Table 1 Construct of measuring technological dynamics of new technology of

\begin{tabular}{|c|c|c|}
\hline \multicolumn{2}{|c}{ the industry } \\
\hline TECH_DYN1 & $\begin{array}{c}\text { Particle } \\
\text { Technological changes are } \\
\text { creating new opportunities in } \\
\text { our industry }\end{array}$ & $\begin{array}{c}\text { Likert scale (1 - } \\
\text { strongly disagree, 5 } \\
\text { - strongly agree) }\end{array}$ \\
\hline TECH_DYN2 & $\begin{array}{c}\text { Technology is changing } \\
\text { rapidly in our industry }\end{array}$ & $\begin{array}{c}\text { Likert scale (1 - } \\
\text { strongly disagree, 5 } \\
\text { - strongly agree) }\end{array}$ \\
\hline TECH_DYN3 & $\begin{array}{c}\text { We expect growth in our } \\
\text { industry over the next five } \\
\text { years }\end{array}$ & $\begin{array}{c}\text { Likert scale (1 - } \\
\text { strongly disagree, 5 } \\
\text { - strongly agree }\end{array}$ \\
\hline
\end{tabular}

Table 2 Construct of measuring representation of social media (networks) (new technology) in business strategy [13]

\begin{tabular}{|c|c|c|}
\hline Code & Particle & Modality \\
\hline M1 & $\begin{array}{c}\text { The top/senior management of our } \\
\text { firm actively articulates a vision for } \\
\text { the organizational use of new } \\
\text { technology }\end{array}$ & $\begin{array}{c}\text { Likert scale (1 - } \\
\text { strongly disagree, 5 } \\
\text { - strongly agree) }\end{array}$ \\
\hline M2 & $\begin{array}{c}\text { The top/senior management of our } \\
\text { firm actively formulated a strategy } \\
\text { for the }\end{array}$ & $\begin{array}{c}\text { Likert scale (1 - } \\
\text { strongly disagree, 5 } \\
\text { - strongly agree) }\end{array}$ \\
\hline
\end{tabular}

\subsection{Company Characteristics}

In order to present the results of the research, it is necessary to define and explain the characteristics of the companies that were part of the research sample. Tab. 3 (authors research work, 2019) shows the size of the firms involved in the survey.

\subsection{Testing the Set Research Hypothesis}

Appropriate statistical methods and tests were applied to test the set research hypothesis. The course of data analysis is as follows: (1) scale reliability testing, (2) 
assumption testing for regression analysis, (3) analysis to investigate relations (correlation and multiple regression). From the performed analyses, reliability and normality, input and output data, it was proved that the preconditions for the implementation of linear regression analysis were met.

Table 3 Company size and number of employees

\begin{tabular}{|c|c|c|c|}
\hline & $\begin{array}{l}\text { Number of } \\
\text { companies }\end{array}$ & $\begin{array}{l}\text { Structure } \\
\text { in } \%\end{array}$ & $\begin{array}{c}\text { Cumulative } \\
\%\end{array}$ \\
\hline $\begin{array}{l}\text { Micro company (less than } \\
10 \text { employees, annual } \\
\text { turnover in the amount up to } \\
\text { EUR } 2,000,000.00 \text { ) }\end{array}$ & 73 & 38 & 38 \\
\hline $\begin{array}{l}\text { Small company (less than } 50 \\
\text { employees, annual turnover } \\
\text { up to EUR } 10,000,000.00 \text { ) }\end{array}$ & 48 & 25 & 63 \\
\hline $\begin{array}{l}\text { Medium-sized company } \\
\text { (less than } 250 \text { employees, } \\
\text { annual turnover of up to } \\
\text { EUR } 50,000,000.00 \text { ) }\end{array}$ & 35 & 18 & 81 \\
\hline $\begin{array}{l}\text { Large company (more than } \\
250 \text { employees, annual and } \\
\text { turnover in the amount of } \\
\text { more than EUR } \\
50,000,000.00)\end{array}$ & 38 & 19 & 100 \\
\hline TOTAL & 194 & 100,00 & \\
\hline
\end{tabular}

One of the prerequisites for performing regression analysis is the existence of a linear relationship between the variables. In this case, the dependence of one phenomenon on two or more independent phenomena is examined, which justifies the method of testing hypothesis $\mathrm{H} 1$ through multiple regression and correlation.

Research wanted to investigate and prove whether new technologies and their technological dynamics affect company top management in the context of the acceptance and the representation of new technologies (social media) in the business strategy of Croatian export companies. The research hypothesis consists of two constructs. The first construct is: "New technologies and technological dynamics" (Tab. 1) while the second is "Representation of new technologies (social media/networks) in the business strategy" (Tab. 2).

In order to test the set hypothesis H1, the following relationships were set: independent variable TECH_DYN "New technologies and technological dynamics" (variables: TECH_DYN1, TECH_DYN2, TECH_DYN3) and dependent variable $M$ "Representation of new technologies (social media/networks) in business strategy (variables: M1 and M2). Regression was tested by testing the relationship and correlation of the independent variables with each of the dependent variables. The research includes the relationship between three (3) independent and two (2) dependent variables, of which correlations and relationships with both dependent variables M1 and M2 were confirmed by mutual testing through regression analysis, which is shown below.

Table 4 Representativeness indicators of the regression model with the dependent variable M1

\begin{tabular}{|c|c|c|c|c|}
\hline Model & $R$ & $R$ Square & $\begin{array}{c}\text { Adjusted } R \\
\text { Square }\end{array}$ & $\begin{array}{c}\text { Std. Error of } \\
\text { the Estimate }\end{array}$ \\
\hline 1 & 0,338 & 0,114 & 0,100 & 1,136 \\
\hline
\end{tabular}

Tab. 4 (authors processing research, June 2020.) presents the representativeness indicators of the regression model, with the dependent variable M1 (The top/senior management of our firm actively articulates a vision for the organizational use of new technologies). The coefficient of determination indicates that the model interpreted $11,4 \%$ of the variance deviation from the dependent variable.

Table 5 Anova analysis of the regression model - Dependent Variable M1

\begin{tabular}{|c|c|c|c|c|c|c|}
\hline \multicolumn{2}{|r|}{ Model } & $\begin{array}{c}\text { Sum of } \\
\text { Squares }\end{array}$ & $d f$ & $\begin{array}{l}\text { Mean } \\
\text { Square }\end{array}$ & $F$ & Sig. \\
\hline \multirow{3}{*}{1} & Regression & 31,557 & 3 & 10,519 & 8,155 & $\begin{array}{c}0,000 \\
* * *\end{array}$ \\
\hline & Residual & 245,067 & 190 & 1,290 & & \\
\hline & Total & 276,624 & 193 & & & \\
\hline
\end{tabular}

Tab. 5 (authors processing research, June 2020.) shows Anova's analysis of the regression model with the dependent variable M1 (The top/senior management of our firm actively articulates a vision for the organizational use of new technologies). Anova test is statistically significant with $1 \%$ probability, and it can be concluded that at least one of the independent variables has a statistically significant impact on the dependent variable M1 (The top/senior management of our firm actively articulates a vision for the organizational use of new technologies).

Anova analysis tests whether $R$ can be 0 . If Sig is less than 0,05 ; the hypothesis that $\mathrm{R}$ is zero is rejected, in which case we have enough statistical evidence that the correlation is different from zero, allowing the independent variable TECH_DYN "New technologies and technological dynamics" (variables: TECH_DYN1, TECH_DYN2, TECH_DYN3) has an impact on the dependent variable M1 (The top/senior management of our firm actively articulates a vision for the organizational use of new technologies). If $R$ were zero, the independent variables would have no effect on the dependent variable.

Tab. 6 (authors processing research, June 2020) shows the estimation of the parameters of the regression model with the dependent variable M1 (The top/senior management of our firm actively articulates a vision for the organizational use of new technologies). One independent variable has a statistically significant effect on the dependent variable. Independent variable TECH_DYN1 (Technological changes are creating new opportunities in our industry) has a statistically significant positive impact on the dependent variable with $10 \%$ probability.

\begin{tabular}{|c|c|c|c|c|c|c|}
\hline & \multirow{2}{*}{ Model } & \multicolumn{2}{|c|}{$\begin{array}{l}\text { Unstandardized } \\
\text { Coefficients }\end{array}$} & \multirow{2}{*}{$\begin{array}{c}\begin{array}{c}\text { Standardized } \\
\text { Coefficients }\end{array} \\
\text { Beta }\end{array}$} & \multirow{2}{*}{$t$} & \multirow{2}{*}{ Sig. } \\
\hline & & $B$ & $\begin{array}{l}\text { Std. } \\
\text { Error }\end{array}$ & & & \\
\hline \multirow{4}{*}{1} & (Constant) & 1,808 & 0,308 & & 5,864 & 0,000 \\
\hline & TECH_DYN1 & 0,212 & 0,110 & 0,194 & 1,926 & $\begin{array}{c}0,056 \\
* *\end{array}$ \\
\hline & TECH_DYN2 & 0,076 & 0,101 & 0,079 & 0,752 & 0,453 \\
\hline & TECH DYN3 & 0,114 & 0,104 & 0,106 & 1,098 & 0,274 \\
\hline
\end{tabular}

Table 7 Representativeness indicators of the regression model with the dependent variable $\mathrm{M} 2$

\begin{tabular}{|c|c|c|c|c|}
\hline Model & $R$ & $R$ Square & $\begin{array}{c}\text { Adjusted } R \\
\text { Square }\end{array}$ & $\begin{array}{c}\text { Std. Error of } \\
\text { the Estimate }\end{array}$ \\
\hline 1 & 0,298 & 0,089 & 0,074 & 1,193 \\
\hline
\end{tabular}

Tab. 7 (authors processing research, June 2020) presents the representativeness indicators of the regression model, with the dependent variable M2 (The top/senior 
management of our firm actively formulated a strategy for the organizational use of new technology). The coefficient of determination indicates that the model interpreted $8,9 \%$ of the variance deviation from the dependent variable.

Tab. 8 (authors processing research, June 2020) shows Anova's analysis of the regression model with the dependent variable M2 (The top/senior management of our firm actively formulated a strategy for the organizational use of new technology). The Anova test is statistically significant with a $1 \%$ probability, suggesting that at least one of the independent variables has a statistically significant effect on the dependent variable M2.

Table 8 Anova analysis of the regression model - Dependent Variable M2

\begin{tabular}{|c|c|c|c|c|c|c|}
\hline \multicolumn{2}{|r|}{ Model } & $\begin{array}{c}\text { Sum of } \\
\text { Squares }\end{array}$ & $d f$ & $\begin{array}{l}\text { Mean } \\
\text { Square }\end{array}$ & $F$ & Sig. \\
\hline \multirow{3}{*}{1} & Regression & 26,290 & 3 & 8,763 & 6,157 & $\begin{array}{c}0,001 \\
* * *\end{array}$ \\
\hline & Residual & 27,432 & 190 & 1,423 & & \\
\hline & Total & 296,722 & 193 & & & \\
\hline
\end{tabular}

Tab. 9 (authors processing research, June 2020) shows the estimation of the parameters of the regression model with the dependent variable M2 (The top/senior management of our firm actively formulated a strategy for the organizational use of new technology). One independent variable has a statistically significant effect on the dependent variable. Independent variable TECH_DYN2 (Technology is changing rapidly in our industry) has a statistically significant positive impact on the dependent variable with $10 \%$ probability.

\begin{tabular}{|c|c|c|c|c|c|c|}
\hline & \multirow{2}{*}{ Model } & \multicolumn{2}{|c|}{$\begin{array}{c}\text { Unstandardized } \\
\text { Coefficients }\end{array}$} & \multirow{2}{*}{$\begin{array}{c}\begin{array}{c}\text { Standardized } \\
\text { Coefficients }\end{array} \\
\text { Beta }\end{array}$} & \multirow{2}{*}{$t$} & \multirow{2}{*}{ Sig. } \\
\hline & & B & $\begin{array}{l}\text { Std. } \\
\text { Error }\end{array}$ & & & \\
\hline \multirow{4}{*}{1} & (Constant) & 1,983 & 0,324 & & 6,125 & 0,000 \\
\hline & TECH_DYN1 & 0,097 & 0,116 & 0,086 & 0,841 & 0,401 \\
\hline & TECH_DYN2 & 0,205 & 0,106 & 0,207 & 1,940 & $0,054 * *$ \\
\hline & TECH_DYN3 & 0,036 & 0,109 & 0,032 & 0,330 & 0,742 \\
\hline
\end{tabular}
Note: ${ }^{*} 10 \%$ significance

Through the conducted research, it has been proven that new technologies and their technological dynamics have an impact on the top management of Croatian export companies from the aspect of the representation of new technologies in the business strategy. The research confirmed that new technologies and their technological dynamics affect top management, and confirmed that in today's international and global market, new technologies and their technological dynamics create pressure on top management from the aspect of accepting new technologies that is its vision and integration within the business strategy which today affects competitive advantage and sustainable development. The management of Croatian export companies is aware of the importance of new digital technologies and its technological development and its impact on the creation of added value and sustainable development, which was confirmed by this research. The digital development strategy of the company, ie the integration and inclusion of IT strategy within the corporate strategy is a prerequisite for long-term growth and development of export companies that operate globally and internationally. Considering the structure of respondents' responses related to variable testing of the dependent variable $M$ "The representation of new technologies (social media (network)) in business strategy" is shown in Tab. 10 (authors processing research, June 2020), where is shown the structure of respondents' responses to variables M1 (The top/senior management of our firm actively articulates a vision for the organizational use of new technologies) and M2 (The top/senior management of our firm actively formulated a strategy for the organizational use of new technology). As can be seen through Tab. 10, looking at the M1 variable, 35\% of respondents assign a grade 3 (three) (neither agree nor disagree) while $30 \%$ of respondents assign a grade of 4 (four) (agree) to the M2 variable. The research proved that the management of Croatian export companies recognizes the importance of integrating IT strategy (digital technology strategy) within the corporate strategy, but it is clear that there is still a gap in which one part of the management of Croatian export companies does not recognize the importance of digital technologies and their integration within corporate strategy which leaves space for new and further research in this area.

Table 10 Structure of respondents' answers to the representation of new technologies (social media/networks) in the business strategy

\begin{tabular}{|c|c|c|c|c|c|c|}
\hline & 1 & 2 & 3 & 4 & 5 & Total \\
\hline \multirow{2}{*}{ M1 } & 15 & 36 & 67 & 37 & 39 & 194 \\
& $(8 \%)$ & $(18 \%)$ & $(35 \%)$ & $(19 \%)$ & $(20 \%)$ & $(100 \%)$ \\
\hline \multirow{2}{*}{ M2 } & 21 & 43 & 42 & 59 & 29 & 194 \\
& $(11 \%)$ & $(22 \%)$ & $(22 \%)$ & $(30 \%)$ & $(15 \%)$ & $(100 \%)$ \\
\hline
\end{tabular}

\section{CONCLUSION}

Internationalization and globalization of markets in almost all industries leads to research into new technologies and research into the benefits and advantages that new technologies provide to companies. Digital business transformation involves the transformation of key business models and affects products and processes as well as the organizational structure and management concepts. Businesses need to establish procedures how to adopt, implement and use new technologies in order to be able to manage these complex business transformations well. A very important step in the digital transformation of business is the formulation of a digital strategy, the inclusion of IT/digital strategy within the corporate strategy of the company (digital transformation strategy).

The research proved that the top management of Croatian export companies understands the importance of using new technologies in today's global and international market. Technological dynamics of new technologies creates pressure on the management of export companies, which creates a vision of using new technologies that leads to the development of digital strategies and its integration within the corporate strategy necessary for the growth and development of companies in accordance with digital market needs. The management of Croatian export companies recognizes the importance and significance of the development of an IT strategy (digital business strategy) which becomes an integral part of the corporate business strategy and which ensures the long-term growth and development of the company. 


\section{REFERENCES}

[1] Martinčević, I. (2020). Influence of the use of social networks on the export activity of Croatian export companies. Doctoral thesis.

[2] Clerck, J. (2017). Digitization, digitalization and digital transformation: the differences. i-SCOOP. Available at https:/www.i-scoop.eu/digitization-digitalization-digitaltransformation-disruption/

[3] Thomas, H., Christian, M., Alexander, B., \& Florian, W. (2016). Options for formulating a digital transformation strategy. MIS Quarterly Executive, 15(2).

[4] Gruman, G. (2016). What digital transformation really means. Info World.

http://www.infoworld.com/article/3080644/itmanagement/what-digital-transformationreally-means.html

[5] Li, F. (2018). The digital transformation of business models in the creative industries: A holistic framework and emerging trends. Technovation, 92, 102012. https://doi.org/10.1016/j.technovation.2017.12.004

[6] Westerman, G., Bonnet, D., \& Mcafee, A. (2014). The nine elements of digital transformation. MIT Sloan Management Review. https://sloanreview.mit.edu/article/the-nineelements-of-digitaltransformation

[7] Sebastian, I. M., Ross, J. W., Beath, C., Mocker, M. Moloney, K. G., \& Fonstad, N. O. (2017). How big old companies navigate digital transformation. MIS Quarterly Executive, 16(3), 197-213.

[8] Porter, M. E. (2008). Konkurentska prednost: Postizanje $i$ održavanje vrhunskog poslovanja. Zagreb, Masmedia.

[9] Dunković, D., (2000). Strateško usmjerenje menadžmenta prema modernoj informacijskoj tehnologiji u hrvatskim tvrtkama. Ekonomski vjesnik: Review of Contemporary Entrepreneurship, Business, and Economic Issues,1(2), 6379 .

[10] Vernet, M. \& Arasti, M. R. (1999). Linking Business Strategy to Technology Strategies: A Prerequisite to the R \& D Determination. International Journal Technology Management, 18(3/4). https://doi.org/10.1504/IJTM.1999.002776

[11] Matt, C., Hess, T., \& Benlian, A. (2015). Digital Transformation Strategies. Bus. Inf. Syst. Eng., 57(5), 339343. https://doi.org/10.1007/s12599-015-0401-5

[12] Hausberg, J. P., Liere-Netheler, K., Packmohr, S., Pakura, S., \& Vogelsang, K. (2019). Research streams on digital transformation from a holistic business perspective: a systematic literature review and citation network analysis. Journal of Business Economics, 89, 931-963. https://doi.org/10.1007/s11573-019-00956-z

[13] Bharati, P., Zhang, C., \& Chaudhury, A. (2014). Social media assimilation in firms: Investigating the roles of absorptive capacity and institutional pressures. Information Systems Frontiers, 6(1), 1-33

\section{Contact information:}

Ivana MARTINČEVIĆ, PhD

(Corresponding author)

University North,

Trg Žarka Dolinara 1

48000 Koprivnica, Croatia

E-mail: ivana.martincevic@unin.hr

Goran KOZINA, Professor, PhD

University North,

Trg Žarka Dolinara 1,

48000 Koprivnica, Croatia

E-mail: goran.kozina@unin.hr 